\title{
173. 中耳圧の前庭への影響
}

\author{
一一前庭水管，蝸牛水管の役割—
}

鉄木幹男・北野博也・北原正章（滋賀医大）

目的 飛行中や潜水中にパイロットやダイバーが起 こすめまいは alternobaric vertigo として知られてい る. 中耳圧変化が前庭に影響を及ぼしこれらの症状を 引き起こすと考光られる。我々は昨年の本学会で中耳 压変化は括もに正円空を経由して内耳に影響を与える ことを報告した。中耳圧変化により引き起こされた内 耳圧変化は前庭水管，蝸牛水管により緩衝される。今 回，前庭水管，螖牛水管を閉鎖したモルモットを用い て中耳圧による前庭神経活動変化抢よび内耳王変化を 測定しこれらの役割につき報告した。

方法 1) 前庭神経 1 次ニューロン活動の変化：対 昭群，前庭水管閉鎖群，螻牛水管閉鎖群にそれぞれ18 匹，9匹，7匹の白色モルモットを用いた。後頭蓋窩 を開頭し小脑の一部を吸引除去し，上前庭神経節を明 視下においた，微小電極を刺入し前庭神経 1 次ニュー ロン放電を細胞外記録した。压負荷用チューブは中耳 控内に留置し, + $-100 \mathrm{mmH}_{2} \mathrm{O} / \mathrm{sec}$ の速さで+一 $500 \mathrm{~mm} \mathrm{H}_{2} \mathrm{O}$ まで変化させ，30秒間一定の圧に保った。 この压負荷による前庭神経放電の変化を記録した。前 庭水管，蛤牛水管の閉鎖は頭蓋内からデンタルセメン 卜を用いて行った，2）中耳圧変化に伴う内耳圧変化：
WPI 製 micropressure system Model 900 を用い蝸牛 基底回転前庭階から内耳圧変化を測定した，対照群， 前庭水管閉鎖群，螖牛水管閉鎖群に各 5 匹の白色モル モットを用いた，中耳耹負荷の条件を+ とした以外はすべて1)と同様の条件で測定した。

結果 1. 前庭水管閉鎖群では前庭神経活動の変化, 内耳压変化は対照群とほぼ同様であった。2．蝸牛水管 閉鎖群では前庭神経活動の変化, 内耳王変化はいずれ も刘照群と比ベ大きかっった。

考案 中耳压変化にともなう内耳王変化如前庭水 管，蝸牛水管により緩衝される，今回の実騒結果から 蝸牛水管は圧変化を緩衝することにより前庭機能異常 を防ぐ動きがあると考えられる。一方，前庭水管は今 回のような急激な圧变化に際しては余り重要な働きを していないと考えられる。貿問 西原信成(要媛 大). 螖牛水管, 前庭水管を閉鎖した場合の内耳压波形 はどうか. 応答 開頭群と前庭水管閉鎖群との間 に差はなく，蝸牛水管閉鎖群では圧変化の減少が他の 2 群上り少なかった。 質問 中井義明(大阪市大). 内リンパ水腫耳ではどのようになるか. 応答 水 腫耳在動物ではまだ検討していない。

\section{4. 外耳圧の内耳への伝達機序に関する実験的研究}

\section{西原信成（愛媛大）}

気圧の変化により急性の感音性難㯖が発症すること が知られているが，そのメカニズムに関しては十分に 研究されておらず，外耳道の圧変化が内耳によ゙のよう にして障害を及ぼすかに関する知見は少ない。本研究 は外耳道内に加えられた圧がどのような機序で内耳に 伝えられるかを明らかにすることを目的として行っ た。

実験方法 実験にはモルモットを使用した。気管切 開を行い, 気管力ニューレを䖸入，筋驰緩剂を投与し レスピレーターを用いて調節呼吸を行った。外耳道に チューブを捙入し，インピーダンス・オージオメータ の加隇圧端子に接続, $23.5 \mathrm{mmH}_{2} \mathrm{O} /$ 秒の速度て压を負 荷した. 外耳压，中耳圧は半導体压力トランスデュー サでモニターした。内耳圧の測定にはWPI MODEL 900 Micropressure System を用い, 蝸牛基底回転鼓室 階にプローブを挿入し外リンパの圧変化を測定した。 1) 中耳開放，2）中耳閉鎖，3）耳小学連鎖離断，4）蝠

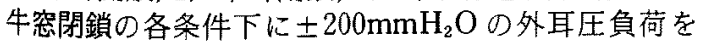
行った.ついで耳管閉鎖処置を行い, $\pm 1000 \mathrm{mmH}_{2} \mathrm{O}$ の圧負荷でも実験它行った。また，外耳圧負荷時の蝸
牛空膜の動きを手術用顥微鏡下に観察した。

害験結果 1) 外耳圧の内耳への伝達は中耳閉鎖時 の方が中耳開放時に比べて大きかった。2) 中耳閉鎖時 には陽圧負荷の方が陰理負荷よりも内耳への圧伝達は 大きかったが，中耳開放時には両者に差はなかった。 3）耳小骨連鎖を離断すると内耳八の圧伝垟は有意に 小さくなり，蝸牛空を閉鎖するとさら炕圧伝達は小さ くなった。4)陽生では+400 $\mathrm{mmH}_{2} \mathrm{O}$, 陰圧では一 $200 \mathrm{mmH}_{2} \mathrm{O}$ の外耳圧負荷までは内耳圧は中耳厓と平 行して変化したが, それ以上の圧魚荷では初圧に戻る 傾向を示した．5）緩徐心外耳圧を変化させた場合には 中耳開放時と中耳閉鎖時では螖牛突膜が逆方向に移動 した。

結論 外耳から内耳への圧伝達において，緩徐に压 負荷が行われた場合には耳小骨連鎖を介する経路より もむしろ中耳腔を介して蝸牛塋加ら内耳八伝達される 割合が大いこと，また，一定以上の圧負荷ては中耳 と内耳に圧差が生じることが明らかとなった。質 問 鈴木幹男 (滋賀医大). 正円空閉鎖の方法は。応 答 蝸牛空は歯科用セメントで閉鎖した。 